\title{
Neurodegenerative diseases: complexity of clinical phenotypes in genetic models of alzheimer's disease and frontotemporal dementia
}

\author{
A C Bruni \\ From de Senectute: Age and Health Forum \\ Catanzaro, Italy. 5-7 December 2009
}

\section{Background}

Neurodegenerative diseases are a wide and complex group of disorders, age - associated, chronic and progressive whith unknown, and probably different, aetiologies. The complexity of the phenotype is probably due to the expression of a selective vulnerability of the different neuronal population and to the different pathogenetic mechanisms. This aetiopathogenetic complexity has been approached through the study of simple models constituted by the large Calabrian families in which Alzheimer's disease (AD) segregates associated to the Presenilin 1 (PS1) Met 146Leu mutation [1] and Frontotemporal dementia (FTD) is caused by the Progranulin (GRN) c1145insA mutation [2].

To investigate the phenotypic variability at onset in patients belonging to the two families for which all data (demographic, clinical and genetic) were available.

\section{Materials and methods}

The clinical presentations were studied in 50 out of 148 familial AD (FAD) patients (age at onset $=40.0 \pm 4.8$; $38 \%$ women, 18 alive) and in 9 out of 34 patients (age at onset $65.1 \pm 17.1$ ) belonging to the FTD family.

\section{Results}

Phenotypic variability at onset in AD is broad: four different clinical presentations may be recognized: 1 ) Amnestic (38\%); 2) Disoriented (20\%); 3) Dysexecutive (14\%); 4) Apathetic (28\%). In the FTD, $89 \%$ of patients presented at onset with a memory deficit and 33\% were spatially disoriented.

Centro Regionale di Neurogenetica, Lamezia Terme, ASP Catanzaro, Italy

\section{Conclusions}

The study conducted on AD and FTD genetic models provides evidence that different genotypes present with a clinical overlapping at onset: symptoms classically associated with FTD are also present in AD and, conversely, FTD patients who are carriers of a PGRN mutation always show a memory deficit. Knowledge advancement calls for a steady upgrade and revision of the clinical criteria routinely used in the diagnostic processing.

Published: 19 May 2010

\section{References}

1. Sherrington R, Rogaev E, Liang $Y$, Rogaeva $E$, Levesque $G$, Ikada $M$, et al: Cloning of a gene bearing missense mutation in early-onset familial Alzheimer's disease. Nature 1995, 375:754-760.

2. Bruni AC, Momeni P, Bernardi L, Tomaino C, Frangipane F, Elder J, et al: Heterogeneity within a large kindred with frontotemporal dementia: a novel progranulin mutation. Neurology. 2007, 69(2):140-147.

doi:10.1186/1471-2318-10-S1-A89

Cite this article as: Bruni: Neurodegenerative diseases: complexity of clinical phenotypes in genetic models of alzheimer's disease and frontotemporal dementia. BMC Geriatrics 2010 10(Suppl 1):A89.

Submit your next manuscript to BioMed Central and take full advantage of:

- Convenient online submission

- Thorough peer review

- No space constraints or color figure charges

- Immediate publication on acceptance

- Inclusion in PubMed, CAS, Scopus and Google Scholar

- Research which is freely available for redistribution 